Historic, Archive Document

Do not assume content reflects current scientific knowledge, policies, or practices. 


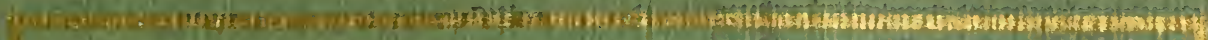

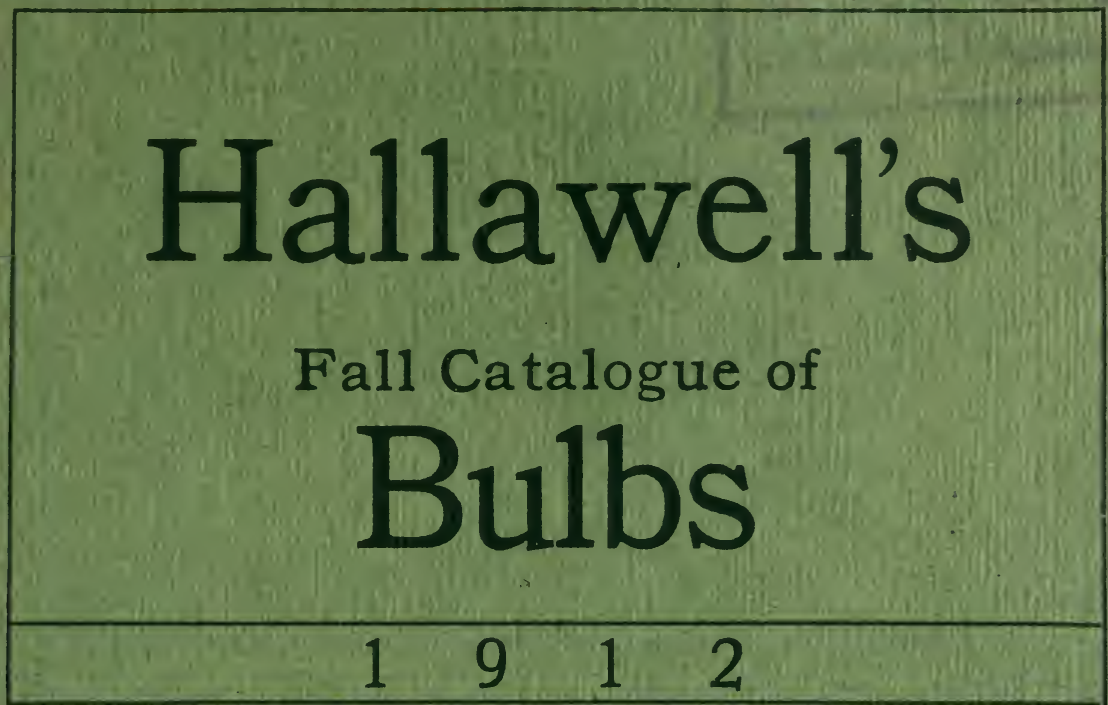

HALLAWELL SEED COMPANY 258 MARKET STRET (NORTH SIDE) SAN FRA NCISCO, CALIFORNIA 


\section{CULTURAL DIRECTIONS}

\section{FOR PLANTING OUR BULBS}

Spring Flowering Bulbs can be planted from September to December. They require a moderately rich soil which should be well drained. If the soil is in poor condition use a little bone meal or well-rotted manure. Fresh manure is injurious to bulbs. When the soil is heavy or stiff, place a small quantity of sand or coal ashes at the base of each bulb. A good rule to go by is to cover the bulbs with soil one and a half times their own depth.

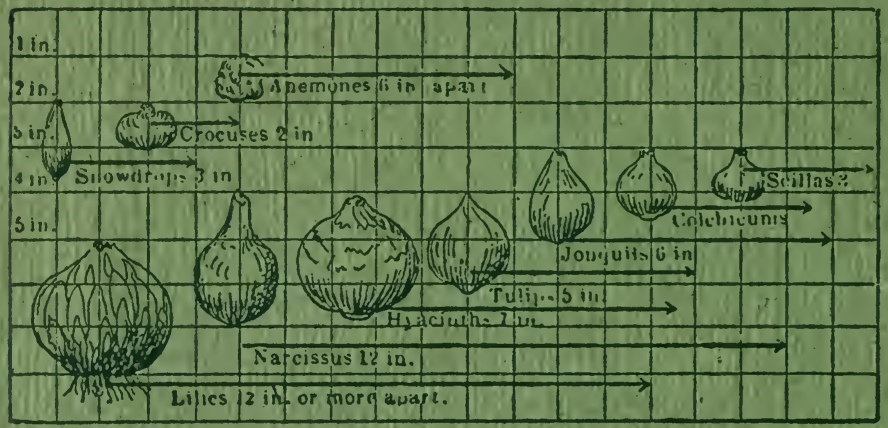

\section{GENERAL CULTURE DIRECTIONS}

\section{DEPTHS AT WHICH BULBS SHOULD BE PLANTED}

The accompanying diagram explains the proper depth to plant bulbs. Outdoor planting should be done early in the fall to obtain best results.

\section{Special Bulb Collection}

10 Hyacinths, mixed

15 Tulips, long stem, mixed

15 Jonquils, Campernelle

15 Freesias, white

15 Ranunculus, mixed
10 Daffodils, trumpets mixed

15 Spanish Iris, mixed

15 Snowdrops, giants

10 Daffodils, mixed

15 Anemones, mixed

\section{Ixias, mixed}

\section{Bulbs for $\$ 2.00$ or half collection of 75 Bulbs for $\$ 1.15$}

The best time to order your bulbs is just as soon as this catalogue reaches you. The bulbs may not have arrived by then, but your order will be given immediate attention, and be filled just as soon as the stock arrives. At the first of the season there are no sorts sold out, and besides the bulbs flower better when planted early.

Please be sure to write plainly your full name and address, when sending us your order and remittance. Send also the name of the nearest express office, if bulbs are to come that way, when it differs from the postoffice. We send bulbs by express, unless postage for the different sorts, as shown in the catalogue, accompanies the order.

\section{Non-Warranty}

Most of the failures with seeds, plants and bulbs are due to causes entirely beyond our control, such as unfavorable weather, too deep or too shallow planting, slugs, etc., therefore Hallawell Seed Co. give no warranty, express or implied, as to description, purity, productiveness, or any other matter of any seeds, plants, bulbs, etc., they send out, and will be in no way responsible for the crop; if the purchaser does not accept the goods on these terms they are to be returned at once. 


\section{Hallawell's "Quality" Tulips}

\section{FOR CALIFORNIA}

The Cottage and Darwin Tulips are more satisfactory for California than the early shorter stemmed varieties, as the large blossoms are borne on strong long stems from 20 to 30 inches tall. They bloom in May and nake a beautiful effect when planted in a bed or in groups.

Tulips can be planted from October till late in December. They require a moderately rich soil which should be well drained. If the soil is in poor condition use a little bone meal or well rotted manure. Plant the bulbs 6 or more inches apart and set the tops 4 inches below the surface. If the soil is heavy, place a small quantity of sand at the base of each bulb. In the following list you will find the leading varieties which are certain to give satisfaction.

(If Tulips are wanted by mail, add 5c per dozen; 35c per 100, for postage.)

Beauty of America : cream color changing slightly pink..

Bridesmaid: rose, striped violet and scarlet

Bouton d'Or: pure golden yellow. Globe shaped.....

Caledonia: orange scarlet, greenish black center, fine bold flower...

Fulgens: large brilliant crimson with white center. Long stems.................

Gesneriana Major: the most popular variety. Large rich crimson scarlet with blue black center. Pointed petals..........

Gesneriana Aurantiaca: large orange-red with pointed petals...............

Gesneriana Lutea: large golden-yellow with pointed petals. Long stems........

Gesneriana Rosea: beautiful rosy-carmine with black center. Long stems and pointed petals.

Isabella or Blushing Bride: creamy white and pink, changing darker rose center, marked peacock blue

La Mervelle: large orange red shaded carmine, sweet scented... .

Maiden's Blush (Picotee): pure white, margined carmine rose. pointed petals. Good pink sort.......................

Macrospila: sweet scented, large crimson

scarlet, black and yellow center..........
Parisian Yellow: large clear yellow,

pointed petals; long stems..............
Retroflexa Yellow: a fine yellow color with petals gracefully bending out.......

Salmon Queen: (Inglescombe Pink): a beautiful blending of buff and salmon pink; a large handsome tulip ..........

Yellow Crown: large golden yellow edged with red....

Special Collection: 2 each of above sorts

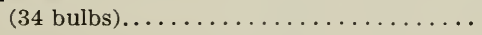

Per doz. Per 100

$\$ .35$

.35
.30

.30

.50

.40

.40

.30

.40

.40

.35

.35

.35

.30

.30

.40

.30

.30

.50

.25

1.35

\section{$\$ 2.50$}

2.00

1.75

3.50

2.50

2.00

2.75

$\mathbf{3 . 0 0}$

35

35

30

0

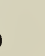

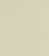

\section{DARWIN TULIPS}

\section{Hallawell's Long Stemmed Tulips}

These Tulips have large cup-shaped flowers which are borne on strong long stems. Late flowering. Any of the following varieties 65c per doz.; $\$ 4.75$ per 100 .

Clara Butt: a beautiful salmon pink. Award of Merit.

Donders: vermilion, violet center.

Europe: salmon scarlet, a bright shade.

General de Cordons: brilliant scarlet.

Glow: scarlet with blue and white center.

Gusta $\nabla$ Dore: bright pink.

Margaret: blush pink, beautiful flower of globular form. Mrs. Krelage: rose pink, extra large.
Mrs. Potter Palmer: glowing purple.

Olga: white and lilac.

Pride of Harlem: salmon rose shaded scarlet. Award. The Sultan: glossy maroon black.

Special Collection: 2 each of above sorts (24 bulbs). for $\$ 1.25$.

Darwin Tulips: splendid mixture of all colors. 30c per doz: $\$ 2.00$ per 100 .

\section{HALLAWELL'S SPECIAL MIXED}

This assortment is made up from named varieties and contains only long stem sorts in all colors. 30c per dozen; $\$ 2.00$ per 100 . 


\section{Tulips-Continued}

Bizarre Tulips mixed: the large blossoms a re feathered or striped with crimson, purple or white on a yellow ground and are borne on long stems.
Perdoz. Per 100

$\$ \quad .30$

$\$ 2.00$

Bybloemen Tulips: the blossoms are borne on long stems and are splashed and striped with blue, lilac, crimson or pink on a white ground. .

Per doz. Per 100

\section{PARROT OR DRAGON TULIPS}

These come in very bright colors, each flower having a combination of red, green, black and yellow. The petals are large and deeply fringed. The stems are rather weak.

Mixture of all colors.

Per doz. Per 100

\section{EARLY SINGLE TULIPS}

For pots, beds and border's. They come in bright colors and bloom in March.

Artus: brilliant, scarlet; good bedder..... Per doz. $\begin{array}{rr}\text { Per } 100 \\ \mathbf{\$ 2 5}\end{array}$

Chrysolora: pure golden yellow, the finest yellow for bedding.

Cottage Maid: soft pink suffused with white; a beautiful variety

Duchess de Parma: orange scarlet with yellow edge, fine and large.

Keizerskroon: red, with broad yellow border...

Prosperine: glossy carmine pink, striking

.30

.30

.30

.40

.60
$\$ 1.75$

2.00

2.00

2.00

2.75

4.25
Pottebakker: Scarlet-bright scarlet, fine

Pottebakker: white-pure white large

Pottebakker: white-pure white, large

showy blossoms.
Pottebakker: Yeliow-bright yellow, fine

and large.

white Hawk: the best pure white, large

Hallawell's Special single Early Mixture: contains a very fine assortment of named varieties made fine assortment of named

splendid Single Early Mixture: good assortment of various colors...........
Per doz. Per 100

$.40 \$ 2.50$

$.40 \quad 2.50$

$.50 \quad 3.75$

$.40 \quad 2.75$

$.30 \quad 2.00$

$.20 \quad 1.25$

\section{EARLY DOUBLE TULIPS}

Per doz. Per 100 forcing or bedding.............. $\$ .40$

Rex Rubrorum: bright crimson scarlet, fine for bedding

Rose Blanche: the best double pure white large..................... .30
$\$ 3.00$

2.75

1.75

Tournesol Yellow: bright yellow

Per doz. Per 100 allawell's Speci... \$ $.40 \quad \$ 3.00$ ture: contains a very fine assortment of double varieties made up by ourselves...

Splendid Double Early Mixture good assortment of various colors........... .25

2.00

\section{Daffodils}

The following list contains the best varieties. Daffodils bloom in March and April. The blossoms are borne on tall strong stems and are fine for cutting. They bloom freely and are very effective when planted in a border or a bed. For pot culture, plant 3 or 4 bulbs in a

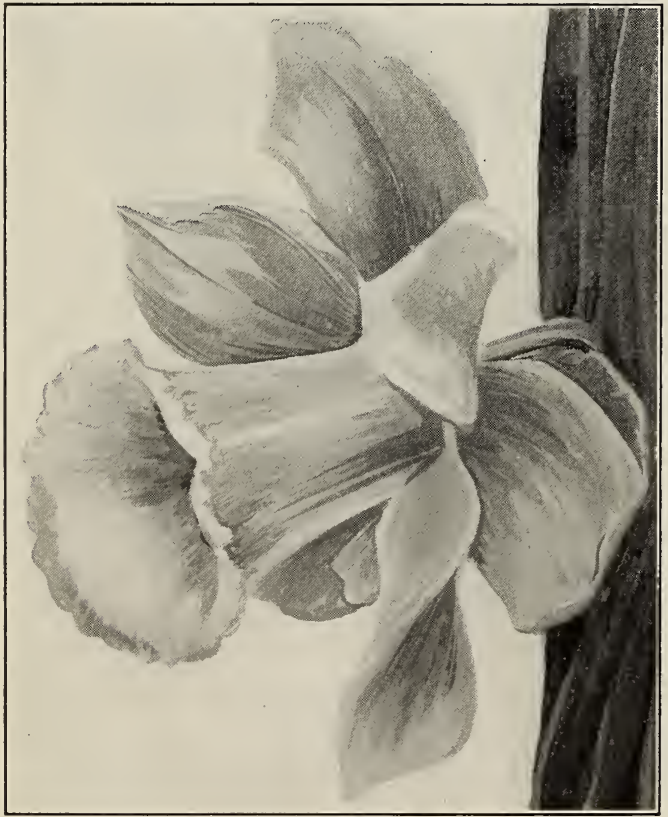

Emperor Daffodil
5 -inch pot and leave the tops of the bulbs just above the surface. After potting give a good watering and set away in a cool cellar until thoroughly rooted, when they can be brought into the house. For outdoor culture set the tops of the bulbs 4 inches below the surface and 12 inches apart.

\section{LARGE TRUMPET DAFFODILS}

(If wanted by mail add 12c per doz. for postage.)

Albicans: ("White Spanish Daffodil") creamy white perianth with a bold silvery

trumpet....................... \$ .50

Bi-color Grandee: flowers of the largest size, with broad, pure white petals and yellow trumpets. Late flowering........

Emperor: the finest yellow, the perianth and trumpet are finely formed and very large. The color is a rich golden yellow.

mpress: a beautiful variety, with a very

large rich yellow trumpet and pure white perianth of great substance. Late flowering.

Per doz. Per 100

$\$ 3.50$

Golden spur: large pure yellow fragrant flowers borne on long stems. Early and extremely free flowering.

Princeps Maximus: sulphur yellow perianth and long deep yellow trumpet. A anth and long deep yellow trumpet. A

very handsome and free blooming sort.....
Trumpet Major: large flowers of a deep

Trumpet Major: large flowers of a deep
golden yellow. Very early and free flowering

victoria: a new daffodil with broad white perianth and large yellow trumpet. Extra 


\section{Hyacinths}

Hyacinths are very fragrant and come in a great variety of colors. They make a magnificent display when grown outside in a bed. They are also very satisfactory when grown in pots or in glasses of water. We are listing the single type only as they are far superior to the double and more certain to bloom. Set the bulbs so that the tops will be 3 or 4 inches below the surface and 6 to 12 inches apart. For pot culture use a 4-inch pot for a bulb or a large pot for 2 or 3 bulbs, with same treatment as given to Daffodils.

\section{BEDDING HYACINTHS}

These are good strong bulbs and will produce fine flowers. (If wanted by mail, add $12 \mathrm{c}$ per doz. for postage.)

blue shades mixed........... .55 $\$ 4.25$

Dark blue shades mixed ............ $\quad .55 \quad \mathbf{4 . 2 5}$

Dark red shades mixed ............. . $55 \quad \mathbf{4 5}$

Rose and pink shades mixed........ $\quad \mathbf{. 5 5} \quad \mathbf{4 . 2 5}$

White shades mixed .............. $\quad .55 \quad \mathbf{4 . 2 5}$

Blush white shades mixed ........... $\quad .55 \quad \mathbf{4 5}$

Yellow shades mixed ............. $\quad .60 \quad \mathbf{4 0}$

All colors mixed................. . $50 \quad 4.00$

\section{NAMED VARIETIES OF HYACINTHS}

(Add 20c per doz. for postage if wanted by mail.) Extra large bulbs for growing in pots and outside.

\section{BLUE}

Grand Maitre: dark porcelain blue, large

truss

Grand Lilas: silvery-lilac, fine spike

King of the Blues: deep purplish blue,

fine spike...........

Leonidas : light blue, large bells ..........

Marie: dark blue, fine spike.............

Queen of the Blues: azure blue, large bells. $\quad .15$

\section{WHITE}

Mad. Van der Hoop: waxy white, large

bells..

Each

Baroness Van Thuyl: pure white, fine

broad truss....................

L'Innocence : large truss of pure white... $\quad \mathbf{. 1 5}$

\section{RED AND PINK}

Gigantea: blush pink

Gertrude: bright rosy red, fine....

Moreno: deep pink

Roi des Belges: crimson scarlet.

Robert Steiger: deep crimson.

Rosea Maxima: delicate large pink.

\section{YELLOW}

Duc de Malakoff: orange yellow...

King of the Yellows: golden yellow

Yellow Hammer: golden yellow, broad

spike.

Collection of twelve named varieties.

Mixture of all varieties.

$\$ 1.25$ per doz
Each Per doz.

$\$ .12$

.15

Each
$\$ .12$

.12

.15

.12

.12

.15

Per doz.

$\$ 1.25$

1.25

1.50

1.25

1.25

1.50

$\$ 1.25$

1.50

1.50

$\$ 1.25$

$\$ 10.00$ per 100 .

\section{FRENCH ROMAN HYACINTHS}

These throw 3 or 4 spikes of dainty florets. They can be grown in pots or outside. Planted in September they flower from Thanksgiving to Christmas time.

(If wanted by mail, add $8 \mathrm{c}$ per doz. for postage.)

\begin{tabular}{|c|c|c|c|}
\hline & Each & Per doz. & Per 100 \\
\hline Pure white. & $\$ .05$ & $\$ .50$ & $\$ 3.75$ \\
\hline Pure white, extra sized. & .07 & .65 & 5.00 \\
\hline Blue ...... & .05 & .50 & 3.75 \\
\hline Pink. & .05 & .50 & 3.75 \\
\hline
\end{tabular}




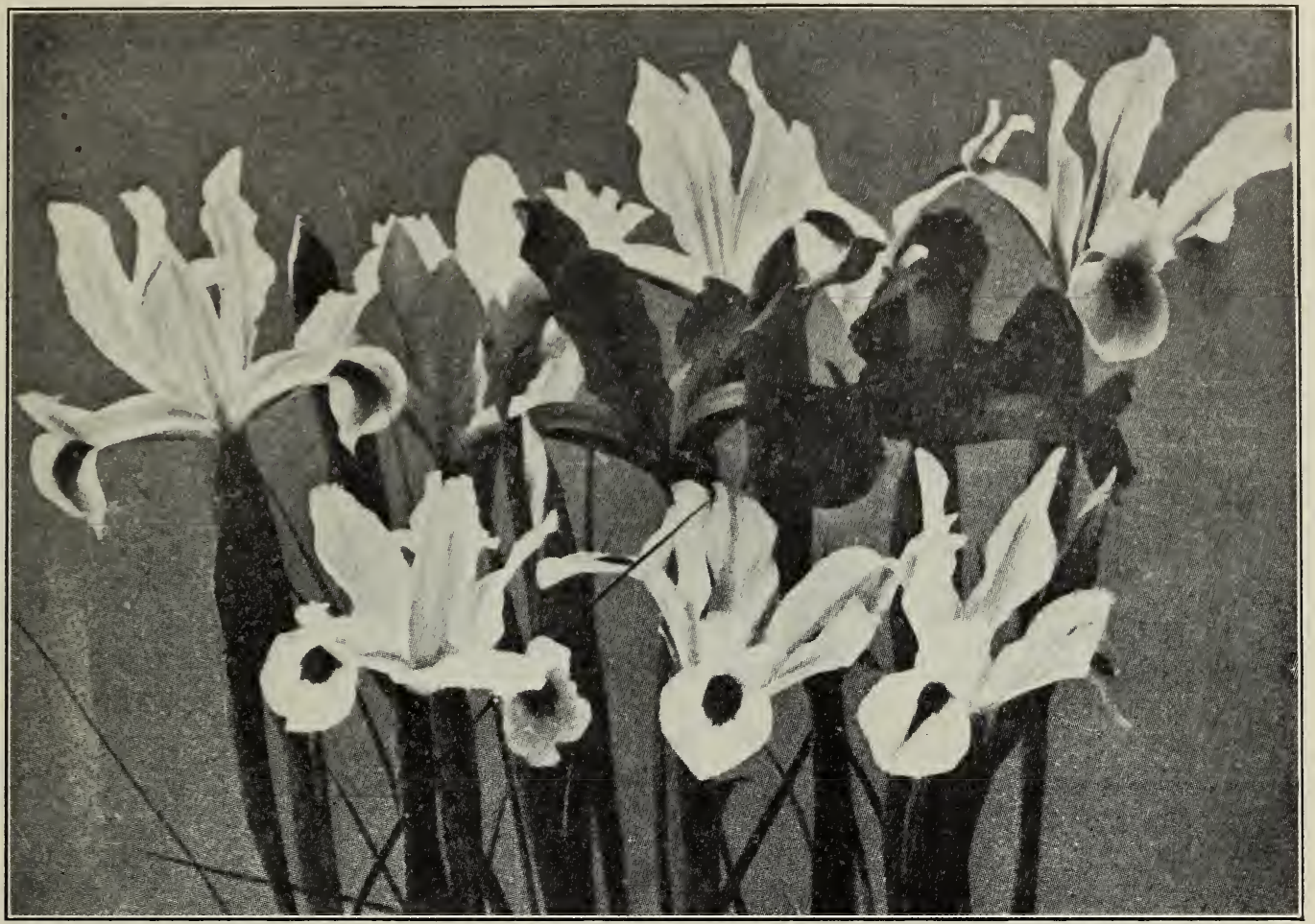

Spanish Iris

\section{Iris or Fleur-de-lis}

Iris are of the simplest culture, succeeding almost in any soil or location. The orchid-like blossoms are borne on tall strong stems and come in a great variety of colors. They are excellent for cutting. For best effect they should be planted in beds or in groups of 25 to 100 or more bulbs. Set the tops of the bulbs 2 or 3 inches below the ground and 6 inches or more apart. Iris succeed better in partial shade.

\section{SPANISH IRIS}

The following list contains only the long stemmed sorts: (Postage 10c per 100.)

Belle Chinoise: deep golden yellow.

Blanche Superbe: pure white, yellow blotch.

British Queen: large pure white.

Cajanus: beautiful deep golden yellow.

Chrysolora: bright yellow.

Darling: large bright blue, long stems.

Formosa: deep violet blue.

Gold Cup: dark bronze.

Louise: fine pale blue, slightly spotted.

Reconnaissance: bronze and orange.

Mixed White Varieties.

Mixed Blue Varieties.

Mixed Yellow Varieties.

All the above varieties.

15c per doz; $\$ 1.00$ per 100 Splendid mixture of all varieties, 2 doz. for $25 \mathrm{c} ; 100$ for $75 \mathrm{c}$; 500 for $\$ \mathbf{3 . 0 0}$.

\section{ENGLISH IRIS}

(If wanted by mail add $5 \mathrm{c}$ per doz. for postage.)

This variety grows 3 feet tall and has larger flowers than the Spanish Iris and blooms later.

\begin{tabular}{|c|c|c|}
\hline Argus: beautiful pink and white.. & $\begin{array}{c}\text { Per doz. } \\
\$ \mathbf{\$ . 4 0}\end{array}$ & $\begin{array}{r}\text { Per } 100 \\
\$ \mathbf{2 . 5 0}\end{array}$ \\
\hline 3leu Celeste: sky blue. . & .40 & 2.50 \\
\hline ing of the Blues: fine deep blue....... & .40 & 2.50 \\
\hline lont Blanc: pure white $\ldots \ldots \ldots \ldots$ & .35 & 2.00 \\
\hline hackeray: rich claret color. & .40 & 2.50 \\
\hline 11 colors mixed. & .25 & 1.75 \\
\hline
\end{tabular}

\section{MOURNING IRIS (Susiana)}

(Postpaid.)

This is a very beautiful and quite distinct variety growing one foot tall and blooming in May. The large flowers are blush tinted brown and covered with a network of fine lines.

15c each; $\$ 1.50$ per doz.

For Japanese Iris and German Iris, see page 6. 


\section{German Iris or Flags}

This variety has beautiful orchid-like flowers and broad foliage which is evergreen. Very suitable for planting in borders in shady places. Plant the bulbs about 1 foot apart.

All the following varieties: $85 \mathrm{c}$ per doz. $\$ 6.00$ per 100 . Bulbs do not ripen until November. (Postage 10c per doz.) Bouquet Royal: creamy white.

Darius: standards light yellow, falls purple, veined yellow and white.

Edward VII: standards blue, falls pale reddish violet.

Honorable: standards golden yellow, falls yellow, heavily veined brown.

Innocenza: ivory white.

Kharput: standards rich blue, falls violet purple.
Madam Chereau: white, elegantly frilled azure blue at the edges.

Maori King: rich golden yellow standards, falls velvety crimson margined gold.

Mrs. Horace Darwin: white slightly veined violet base.

Plicata: white, frilled blue.

Mixture of named varieties: made up by ourselves, $75 \mathrm{c}$ per doz.; $\$ \mathbf{5 . 0 0}$ per 100 .

Mixture, mostly blue shades: . 45c per doz.; $\$ 3.00$ per 100

\section{Japanese Iris}

(December delivery)

This variety of Iris produces the largest and finest flowers in a great variety of colors. They are hardy and do best in partial shade and require plenty of water. They bloom for six weeks during June and July. The flower's measure 8 to 10 inches in diameter and are borne on tall stems. (Too heavy to mail.)

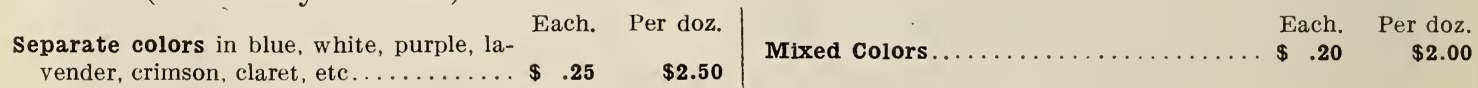

\section{Lilies}

Lilies are matchless amongst hardy plants for beauty of form and variety of color. They commence flowering in June and with various varieties continue blooming until the fall. They succeed better in partial shade and require protection from the wind. Set the tops of the bulbs 5 inches below the surface and 12 inches apart. They require a loose soil with good drainage. October and November delivery. (Postage 3c each, or 25c per dozen if wanted by mail.)

Auratum (Golden Banded Lily): the grandest of all hardy lilies, with large graceful flowers of an ivory white color, thickly studded with chocolate crimson spots and a bright gold band through the center of each petal. 15c and 20c each, and \$1.25 and \$2.00 per doz., according to size.

Auratum Pictum: similar in form to the Auratum, but tipped with crimson at the ends of the yellow rays, 25c each; $\$ 2.50$ per doz.

Auratum Platyphyllum: similar to Áuratum, but larger and finer in all respects. Especially noted for its broad lustrous leaves, which give double attraction. The petals are studded with crimson chocolatespots. 25c each;\$2.50 per doz.

Auratum Rubro Vittatum: one of the finest of all lilies. Its crimson band running through the middle of the petal is so broad that the petals appear to be crimson margined with white; very showy and handsome. The flowers are 10 to 12 inches across, of bright, crimson and white. 50c each; $\$ 5.00$ per doz.

Candidum (St. Joseph or Madonna Lily) ; a very hardy early flowering lily. The pure white flowers are fragrant and are borne on long stems. The best white lily to plant out of doors. (Order in September as bulbs must be planted early). 15c each; $\$ 1.25$ per doz.

Elegans Atrosanguinea: a dark blood-red lily of handsome appearance. Elegans lilies are all borne erect on a stem about $2 \frac{1}{2}$ feet. 20c each; $\mathbf{\$ 2 . 0 0}$ per doz.

Elegans, Incomparable: the richest red known in lilies, a deep crimson slightly spotted black. Flowers large and freely borne. $15 \mathrm{c}$ each; $\$ \mathbf{1 . 5 0}$ per doz.

Elegans, Orange: a very early, flowering lily, doing well in any location, about 2 feet high, flowers are orange in color. 20c each; $\$ 1.75$ per doz.

Leopard Lily: the native Tiger Lily found growing in the mountains in all parts of California. The flowers are borne on tall stems and are scarlet and yellow spotted with brown. 10c each; $\$ \mathbf{1 . 0 0}$ per doz.

Krameri: a beautiful large pink lily, distinct from all others. The flowers shade lighter and are very fragrant. 20c each; $\$ 2.00$ per doz.

Longiflorum Multiflorum: an early flowering type of Japanese Easter Lily with pure white trumpet flowers. 12c each; $\$ 1.00$ per doz.

Extra large bulbs, 20c each; $\$ \mathbf{1 . 7 5}$ per doz.

Longiflorum Giganteum (Japanese Easter Lily): a free flowering lily with pure white trumpet shaped flowers; fine for growing in pots for Easter and very desirable for outdoor planting. $15 \mathrm{c}$ each; $\$ 1.25$ per doz.

Rubellum: of dwarf habit, bearing several beautiful rose-pink flowers. Come into flower early. 20c each; $\$ 2.00$ per doz.

Speciosum Rubrum (Pink Tiger Lily): a strong. vigorous grower, having stems 3 to 4 feet tall with bright blossoms which are white, shaded rose and spotted deep red. 15c each; $\$ \mathbf{1 . 2 5}$ per doz.

Speciosum Melpomene : this variety is similar to the Rubrum but is a deeper crimson. 15c each; $\$ \mathbf{1 . 2 5}$ per doz.

Speciosum Album: a beautiful lily, the flowers are white and the petals recurved. The stems are 3 to 4 feet tall. 15c each; $\$ 1.50$ per doz.

Tigrinum Giganteum (Improved Tiger Lily): a very hardy and free flowering sort. The blossoms are a bright orange color, spotted black. $15 \mathrm{c}$ each; $\mathbf{\$ 1 . 2 5}$ per doz.

Tigrinum Flora Plena (Double Tiger Lily): similar to the Tiger Lily but bearing double flowers. 15c each; $\$ 1.50$ per doz.

Yellow Calla Lily (Elliottiana): the true yellow flowered Calla. The flowers are bright yellow and the foliage dark green, spotted white. 25c and 35c each.

White Calla Lily: strong bulbs. 75 c per doz.; $\$ 5.00$ per 100 . 


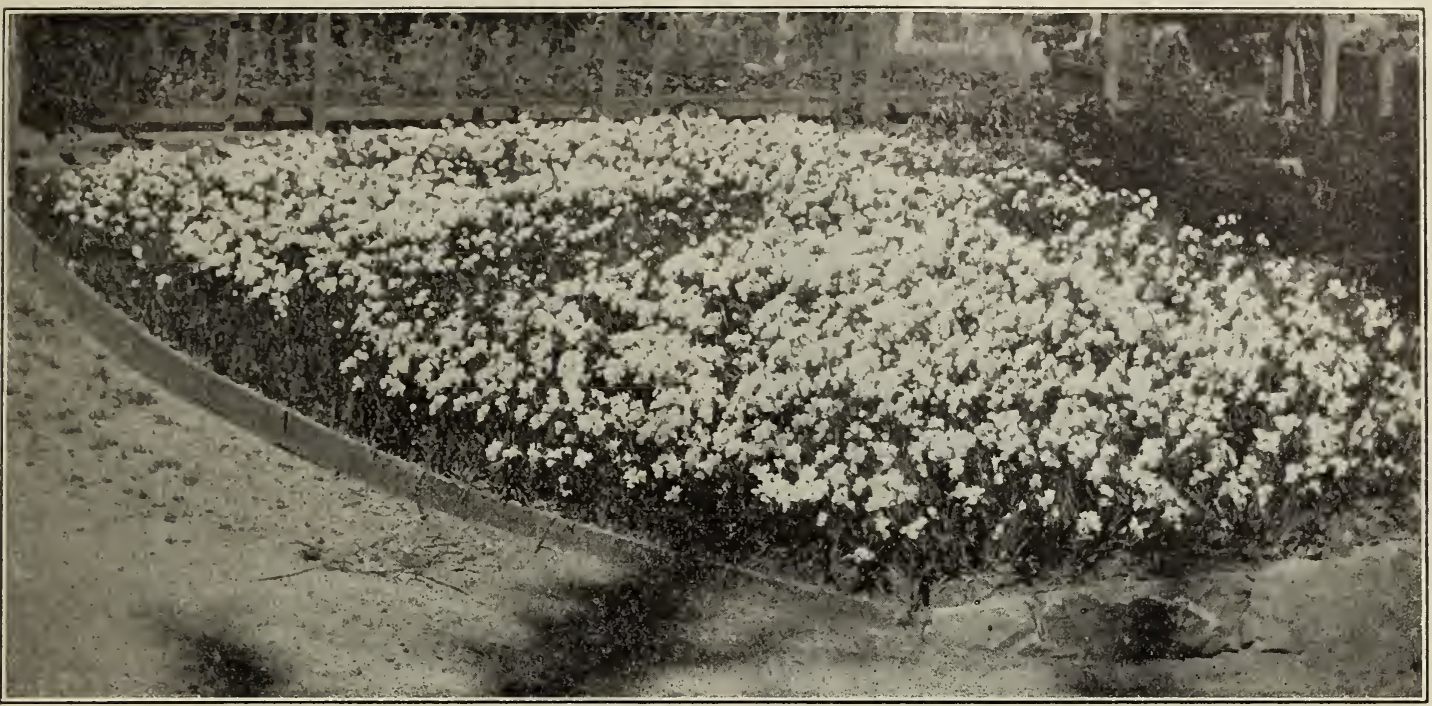

A Bed of Freesias

\section{Miscellaneous Bulbs and Flowering Roots}

\section{AGAPANTHUS UMBELLATUS}

(The Blue African Lily)

The flowers are bright blue and are produced in clusters of 20 to 30 on stalks 3 feet tall. They bloom for a long period in the summer and fall. (Too heavy to mail). 25c each; $\$ \mathbf{2 . 5 0}$ per doz.

\section{AMARYLLIS}

BELLADONNA MAJOR: large beautiful rose-pink trumpet shaped flowers borne on tall leafless stalks. The leaves appearing after the plant is through flowering. They bloom in August and September. (Too heavy to mail). 15c each; $\$ 1.50$ per doz.

\section{ANEMONES (Spring Flowering)}

\section{(Postage 10c per 100)}

The blossoms of the single varieties resemble poppies. The flowers are very beautiful and come in a great variety of dazzling colors. They flower early in spring and make a pretty display when planted in a bed or a border.

Set the tops of the bulbs 1 inch below the surface and 6 inches apart. Soak in water over night before planting. (For illustration see page 8 ).

\section{SINGLE ANEMONES}

Single Blue Per doz.

Sing whide (The Bride).

$\$ .20$

Single Scarlet

Single Mixed.

\section{DOUBLE ANEMONES}

Ceres: white

Duchess de Lorraine: rosy red tinted copper........

Feu Superbe: beautiful scarlet

King of the Blues: a fine deep blue

Double Blue: mixed

Double White: mixed ..............

Double Scarlet: mixed....

Double Mixed

Per 100 $\$ 1.25$

1.25

1.25

1.00

.20

\section{BEGONIA (Tüberous-rooted)}

Splendid pot plants, also useful for bedding outside in partial shade, flowering very profusely.

We offer Begonias in the following separate colors:

Dark rose, light pink, salmon, white, scarlet and yellow.

(Postpaid)

Single: all colors separate or mixed.

Each Per doz.

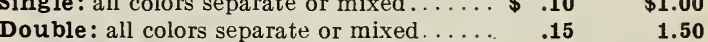

Crispa Mixed : large single flowers beautifully

fringed and crested; all colors separate or

mixed....

.25

2.50

\section{BRODIAEA (Cal. Wild Flower)}

\author{
(Postpaid)
}

Laxa (Ithuriel's Spear): bears a cluster of twenty or more of clear blue flowerets on a stem 1 to 2 feet high. One of the beautiful wild flowers of California in May and June. 20c per doz; \$1.25 per 100 .

\section{CALADIUM OR ELEPHANT'S EAR}

\author{
(For January delivery)
}

\section{CALOCHORTUS OR MARIPOSA TULIPS}

These popular California wild flowers come in a great variety of colors and bloom in May and June.

Mixture of all colors, 30c per doz.; $\$ 2.00$ per 100 .

(Postpaid) 


\section{Miscellaneous Bulbs and Flowering Roots CONTINUED}

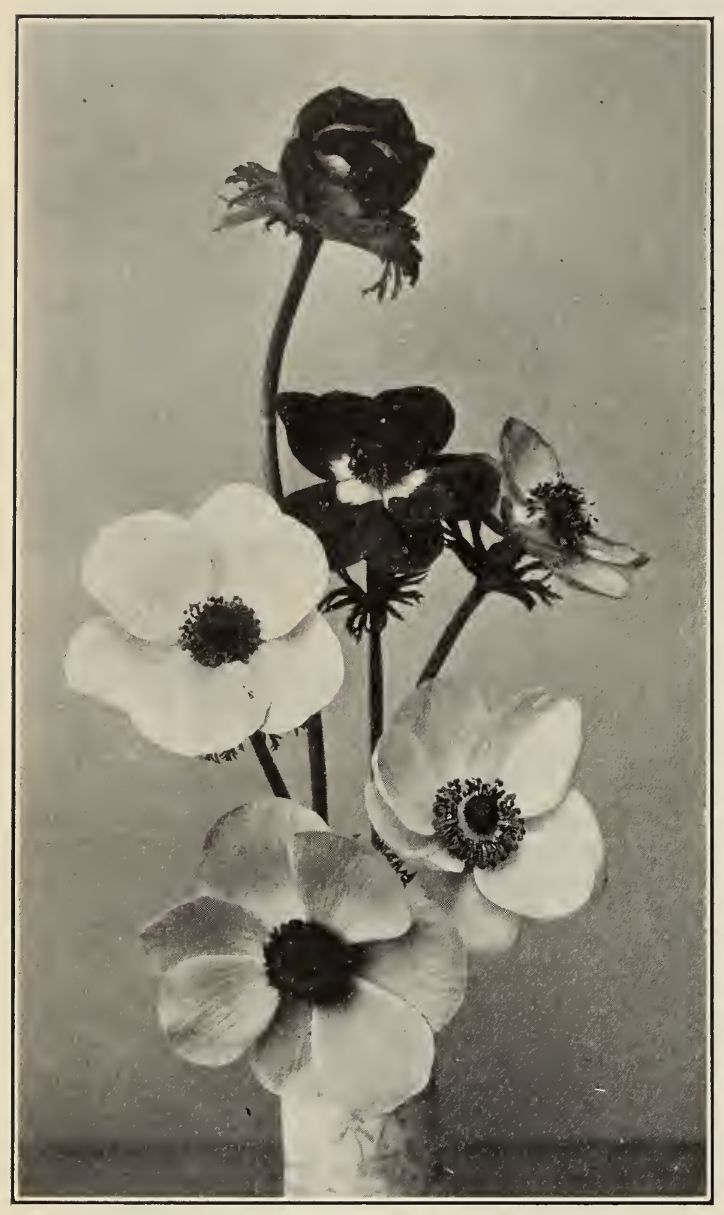

Single Anemones

(For varieties see page 7)

COLCHIUM (Meadow Saffron)

(Autumn Flowering Crocus)

Autumnalis: the flowers come through the ground in the fall without the leaves, which appear next spring. Very similar to a crocus; the colors of the flowers being white, purple, rose striped, etc.

Mixed Colors, 50c per doz.

\section{CROCUS}

One of the earliest spring-flowering bulbs. They are effective when planted in a lawn or in a border 3 or 4 rows deep. Set the tops of the bulbs 2 inches below the surface and 2 to 4 inches apart. For pot culture plant 6 or 8 bulbs in a pot; 1 inch deep.

(Postage 15c per 100)

Blue and Purple: mixed Per doz.

Whites: mixed

$\$ .10$

.10

Striped Varieties: mixed

.10

Yellow: mixed

Yellow: extra large flower.

.10

King of the Blues: extra large flower.

Queen of the Whites: extra large flower ... $\quad .15$

Splendid Mixture of all colors.
$\$ \quad .60$

.60

.60

.60

1.00

1.00

1.00 .50

\section{CROWN IMPERIALS (Fritillaria Imperialis)}

(Postage $3 \mathrm{c}$ each)

A spring flowering hardy border, plants forming large groups if undisturbed for years. The flowers are bell shaped and come in large clusters, surmounted with a tuft of green laves. $15 \mathrm{c}$ each; $\$ \mathbf{1 . 5 0}$ per doz.

\section{CYCLAMEN GIANT FLOWERED PYT}

A beautiful pot plant. The blossoms are curiously winged and are borne on graceful stems. Flowering very profusely for a long period.

\section{(December Delivery)} (Postpaid)

Rose: giant flowered $\ldots \ldots \ldots \ldots \ldots \ldots \ldots \$ \$ .20 \quad \$ 2.00$

Each Per doz.

White: giant flowered ............... $\quad .20 \quad 2.00$

Crimson: giant flowered ............ $\quad .20 \quad 2.00$

Mixed: giant flowered ............. $\quad .20 \quad 1.75$

DIELYTRA OR "BLEEDING HEART"

(For December delivery)

(Postage 8c each)

One of the most ornamental of spring-flowering plants, with long, drooping racemes of heart-shaped flowers. If potted in December, left outside till it has formed new roots and then brought in to a gentle heat it may be had in flower in the greenhouse in February and March.

Spectabilis: magnificent racemes of pink flowers. 20c each; $\$ 2.00$ per doz.

\section{FREESIAS}

They flower very early if planted in September and October. The flowers are born on stems from 9 to 24 inches tall, with 6 to 8 flowers on a stem.

Set the tops of the bulbs 1 inch below the surface and 6 inches apart. (For illustration see page 7)

Per doz. Per 100

Refracta Alba: white, very fragrant.... \$ $.15 \quad \$ 1.00$

Refracta Alba: extra large bulbs....... $\quad .25 \quad 1.50$

Leichtlinil: large, fragrant, light yellow .... $\quad .30 \quad 2.00$

Scarlet: brilliant rosy carmine color, with a dark crimson spot on the three lower petals (December delivery). Postpaid. 25c per doz.; $\$ 1.75$ per 100 .

\section{GLADIOLUS (Early Flowering)}

This type of Gladiolus blooms in May. The flowers are borne on long slender stems; are greatly used for cut flowers.

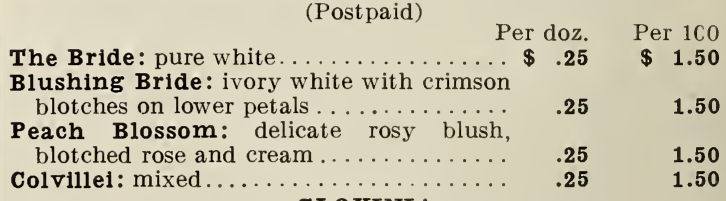

\section{GLOXINIA}

\section{(December Delivery)}

Beautiful pot plants for greenhouse culture. The magnificent tube-shaped flowers measure 3 to 4 inches across. They come in several colors and are very prettily spotted and mottled.

Red, Blue and White, $15 \mathrm{c}$ each; $\$ 1.50$ per doz. (Postpaid) HYACINTHUS CANDICANS

(Postage $3 \mathrm{c}$ per bulb)

Free growing, summer-flowering plants with flower stems 2 to 4 feet high, each bearing from 20 to 30 large white bell shaped flowers; splendid for groups. 7c each; 75c per doz. LILY-OF-THE-VALLEY

(For December and January delivery)

culture or forcing by those who have conservatories

For pot culture excelled, producing large fragrant spikes, crowded with bells, and an abundance of dark green foliage.

Finest Selected Pips for forcing, or for planting either in pots or out of doors; the finest selected grade, bundles of 25 , 65c (75c postpaid); per 100, \$2.50; per 1,000, $\$ 21.00$.

Clumps for outdoor planting, 60c each. Add 10c for post- 


\section{Miscellaneous Bulbs and Flowering Roots--Continued}

\section{IXIAS}

(Postpaid)

They are much admired for their brilliant colors and graceful flower stalks, which resemble a miniature gladiolus. They come in several shades and are fine for cutting, lasting for several days in water. The bulbs should be planted 1 inch deep and from 4 to 6 inches apart, and for best effect should be in beds or groups of 25 to 100 or more bulbs.

be in beds or groups of 25 to 100 or more bubs

Crateroides Major: brilliant scarlet, forces well.

Per 100

Duchess of Edinburgh: white, striped red $\$ .35$

King of the Yellows: yellow with dark purple eye

viridiflora: bright soft green with velvety black center

William the Conqueror: large pure white

wonder (Rosea Plena): deep pink flowers double and very fragrant

splendid Mixture containing a great many

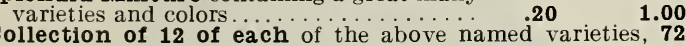

.35
.32 .25 .40 $\mathbf{2 . 2 5}$

.50

2.75

.25

3.50

1.75

.30

2.00 bulbs for $\$ 1.50$.

Half Collection, 36 bulbs for 85c.

\section{MONTBRETIA}

(Postpaid)

A summer flowering bulb, somewhat resembling a gladiolus. The flowers come in shades of orange and yellow and are borne n long Jraceful spikes, and bloom from July to Plant several bulbs in a clump about 2 inches deep.

Mixed varieties: 15c per doz.; $\$ 1.00$ per 100 .

\section{MUSCARI OR GRAPE HYACINTH}

These are dainty little flower spikes bearing curious ballshaped bells in white and blue. Thriving either in partially shaded or sunny locations.

\section{(Postpaid)}

Blue: 15c per doz.; $\$ 1.00$ per 100

White (Pearls of Spain): 20c per doz.; $\$ 1.25$ per 100.

\section{MUSCARI PLUMOSUS}

Feathered Hyacinths, bears plume-like graceful spikes, 9 to 12 inches high, purple in color. 20c per doz.; $\$ 1.25$ per 100 . Postage $5 \mathrm{c}$ per doz. additional.

\section{ORNITHOGAL UM}

Arabicum: a beautiful variety, throwing up a tall spike bearing numerous large, milk-white, star-shaped flowers, with a black center, and having a distinct aromatic perfume. They are of the easiest culture. 5c each; 50c per doz.; $\$ 4.00$ per 100.

\section{OXALIS}

Pretty little half trailing or bushy plants. Adapted for borders and hanging baskets.

$$
\text { (Postpaid) }
$$

Grand Duchess: white

Grand Duchess: pink

Grand Duchess: lavender

Grand Duchess: mixed

Bermuda Buttercup: yeliow

Mixture of all varieties.

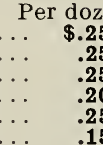

Per 100 $\$ 1.50$ 1.50
1.50 1.50
1.25 1.50

1.00

\section{RANUNCULUS}

These spring flowering bulbs are unrivaled for lovely form and bright colors. The double flowers are borne on stems about 9 inches high. The bulbs have curious finger like projections which should be planted pointing down. Plant 1 inch deep and 6 inches apart. Soak the bulbs in water over night before planting.

\section{(Prices are postpaid)}

$$
\text { Per doz. Per } 100
$$

French Mixed: fine large, double flowers, vigorous grower. Most popular variety. Persian Mixed: very double rose-shaped Turban Mixed: double peony-shaped flow-

\section{SNOWDROPS}

(Postpaid)

California Giants: the finest variety, being three times the size of the common variety. The flowers are pure white, tipped green. 20c per doz.; $\$ 1.00$ per 100 .$$
\text { Sin }
$$

Per 100 $\$ .90$

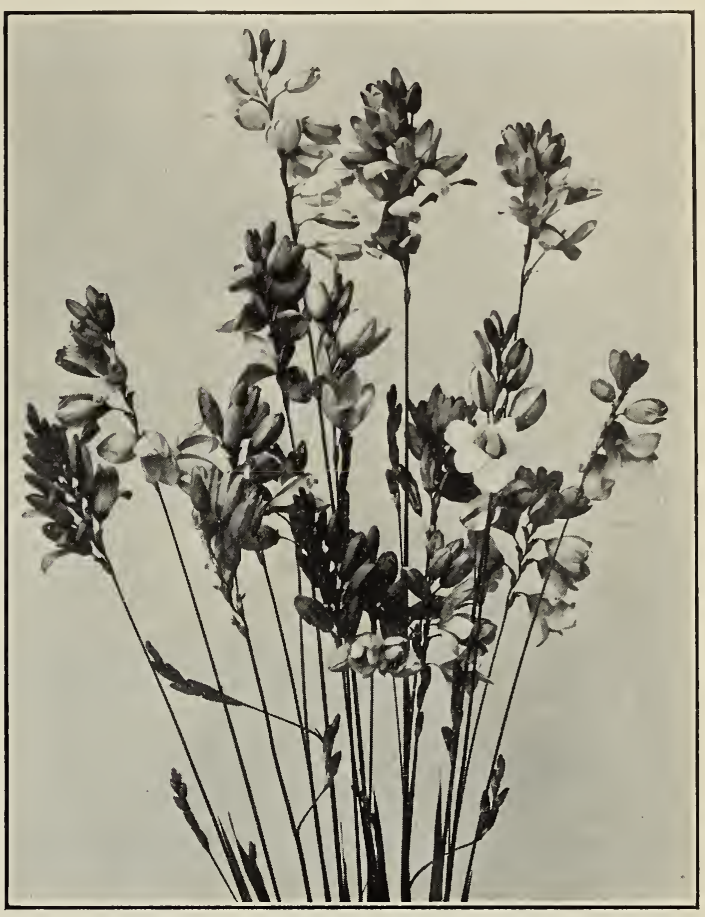

Ixias

\section{SCILLA OR WOOD HYACINTH}

(Price is postpaid)

Charming little bell-shaped flowers that do well under trees or in other shady situations: blossoms very early.

Siberica: exquisite blue, adapted for edging and for growing in clumps. 20c per doz.; $\$ 1.25$ per 100.

\section{SPARAXIS}

(Price is postpaid)

Beautiful flowers borne on long, graceful spikes: the colors are of the most telling combinations and of the brightest shades. They are tigered, blotched, spotted, streaked and flushed in the most diverse and pleasing manner.

Mixed colors : 15c per doz.; 75c per 100

\section{SPIREA}

(Postage 10c each bulb)

(For December Delivery)

While these can be used for outdoor planting where they will bloom during the summer, their great value lies in their ease of culture as a house plant.

Japonica: produces beautiful sprays of silvery white plumes. 20c each; $\$ 2.00$ per doz.

Japonica Compacta Muitiflora: dwarf, and a dense flowerer; clumps; too heavy to mail. $25 \mathrm{c}$ each; $\$ 2.50$ per doz.

Gladstone: (Hybrid Astilboides): the best of all the Spireas,

bearing snow-white plumes in great profusion. 35c each; $\$ 3.50$ per doz.

Queen Alexandra: a splendid new Spirea of a beautiful pink color; a strong grower and free flowerer. When grown indoors it should be kept cool when flowers are developing, this is necessary to bring out the delicate coloring. 50c each; $\$ 4.50$ per doz.

\section{TRITONIA CROCATA}

(Postpaid)

Hardy summer flowering bulbs growing from 9 to 12 inches high. The flowers. which are about 2 inches across, come in shades of tawny vellow and bright orange red.

Mixed colors: 25c per doz.; $\$ 1.50$ per 100

\section{TUBEROSES}

(January Delivery)

(Postage 12c per doz.)

The flowers grow on stems 18 inches high, each stem bearing The flowers grow on stems 18 inches high, each stem bearing very fragrant.

Double Dwarf Pearl: 40c per doz.; $\$ 3.00$ per 100. 


\section{Sweet Peas}

Sow Sweet Pea seed in the months of November and December in order to get them to flower in May and June. They can also be sown any time during the winter or spring for later flowering.

\section{SPENCER OR ORCHID FLOWERED SWEET PEAS}

The finest type of Sweet Pea. The blossoms are large and very wavy with long stems, generally having four blossoms to the stem.

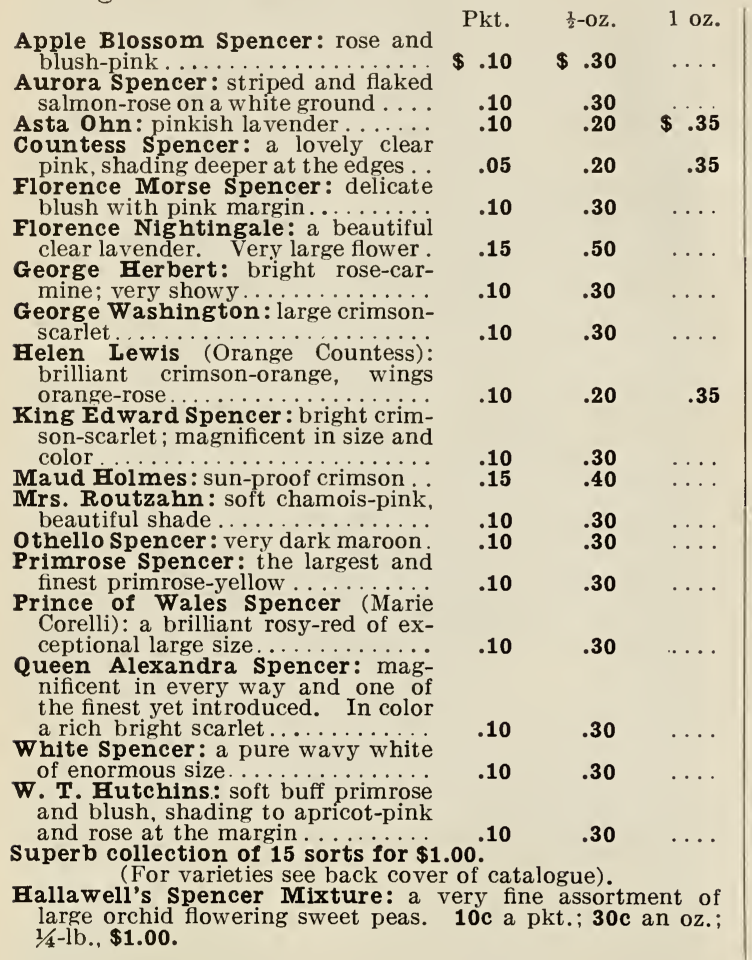

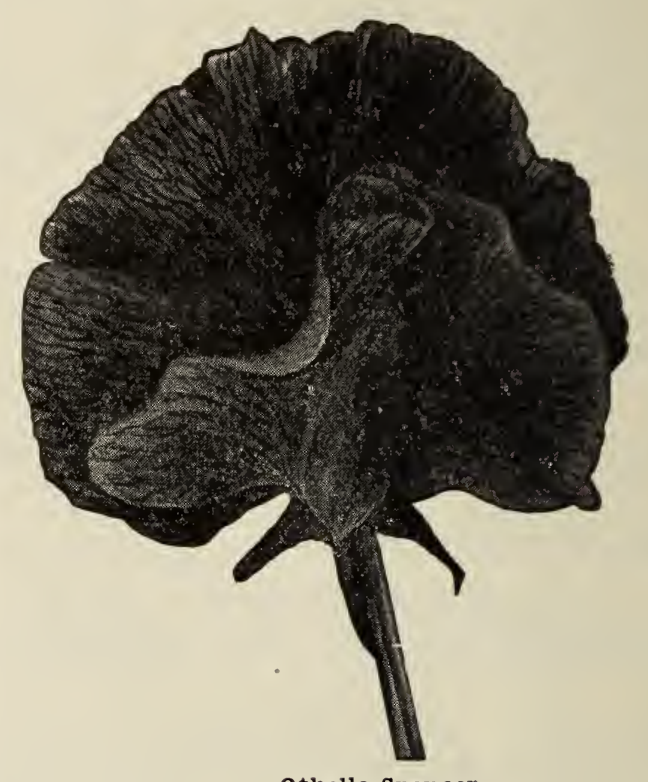

Othello spencer

\section{CHRISTMAS OR EARLY FLOWERING SWEET PEAS}

This class of Sweet Peas will frequently come into bloom in 8 to 10 weeks after sowing the seed. If sown in October, one can have good blossoms by Christmas. Only recommended for early fall planting and for greenhouse forcing.

Burpee's Earliest White: white, black seeded

Christmas Captain: purple and blue

Earliest of All: rose and white......

Christmas Stella Morse: primrose suffused blush....

Earliest Sunbeams: primrose.....

$\begin{array}{rrr}\text { Pkt. } & \text { Oz. } & \text { 1/4-lb. } \\ \$ .05 & \$ .25 & \$ .75 \\ .05 & .25 & .75 \\ .05 & .20 & .50 \\ .05 & .25 & .75 \\ .05 & .25 & .75\end{array}$

Le Marquis: navy blue Meteor: bright scarlet Mont Bianc: white

Mrs. Alex Wallace: pinkish lavender Mrs. C. H. Totty: la vender

Mrs. E. Wilde: crimson scarlet

Mrs. F. J. Delanskey : light pink

Mrs. Wm. Sim: buff pink ......... ture of all early flowering varieties .

$\begin{array}{rrr}\text { Pkt. } & \text { Oz. } & 1 / 4-1 b \\ .05 & .25 & .75 \\ .05 & .25 & .75 \\ .05 & .25 & .75 \\ .05 & .25 & .75 \\ .05 & .25 & .75 \\ .10 & .25 & .75 \\ .10 & .25 & .75 \\ .10 & .25 & .75 \\ .05 & .20 & .60\end{array}$

\section{SELECT LIST OF STANDARD SWEET PEAS}

America: bright red striped and flaked on white ground ........... tinted pink.................... Aurora:

Captain of the Blues : clear purple.

Dainty: white, daintily edged with pink.

Dorothy Eckford: magnificent pure white.

Dobbie's Mid Blue: a very clear bright blue.

Flora Norton: bright sky-blue.
Pkt.

$\$ .05$

.05

.05
.05

.05

.05

.05

.05
Oz. 1/4-lb.

$\$ .20 \$ .50$

$.20 \quad .50$

.20

.20

.20

.20

.20

.20

Gladys Unwin: large and wavy; a light delicate pink, a little deeper at the edges.....................

Helen Pierce: white, veined and mottled bright blue ...........

primrose-yellow King Edward VII: the finest crimson-scarlet

Lady Grisel Hamilton: a grand pale lavender..............

Lord Nelson: the richest deep navybovely: soft shell-pink; a lovely

Pkt. Oz. 1/4-lb.

.10 20c. for $1 / 2-0 z$

$\begin{array}{lll}.05 & .20 \quad .50\end{array}$

$.05 \quad .20 \quad .50$

$.05 \quad .20 \quad .50$

$\begin{array}{lll}.05 & .20 & .50\end{array}$

$\begin{array}{lll}.05 & .20 & .50\end{array}$

$\begin{array}{lll}.05 & .20 & .50\end{array}$ 


\section{Sweet Peas--Continued}

Millie Maslin: a new shade of crimson-red, very la rge and shell-shaped

Miss Willmott: brilliant orangepink; very large

$\$ .10$

Pkt.

$\$ .05$

.05

shade of maure...

Navy Blue: dark indigo blue.

Othello: very dark maroon...

Phenomenal: blue and lavender shaded on white, large and fluff $y . .$.

Prima Donna: a magnificent pure pink....................
.05

.05

$20 \mathrm{c}$ for $\frac{1}{2}-\mathrm{Oz}$. Oz. $1 / 4-1 b$.

$\$ .20 \$ .50$

$.20 \quad .50$

$.20 \quad .50$

$.20 \quad .50$

$.1020 \mathrm{c}$ for $1 / 2 \mathrm{oz}$.
Prince of Wales: the finest bright rose.

Queen Alexandra : bright scarlet .

White wonder: large double, pure white....

Collection of all of the above variet Hallawell's Spencer Mixture, 25 pkts. for $\$ 1.00$. Collection of 7 of any of the above varieties for $25 \mathrm{c}$.

Large Flowering Mixed: a very fine assortment of all the best standard varieties. Pkt., 5c; oz., 10c; 1/4-lb., 30c; $1-1 \mathrm{~b}$. $\$ 1.00$.

\section{CUPID SWEET PEAS}

Dwarf and bushy, growing about 1 foot high and spreading to about 2 feet in diameter. Very effective when planted in a border.

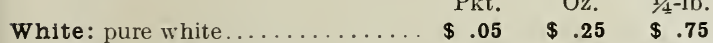

Countess of Radnor: lavender ... $\quad .05 \quad .25 \quad .75$

Prima Donna: pink.

.75
Salopian: red

Mixed : all varieties $\begin{array}{rrr}\text { Pkt. } & \text { Oz. } & 1 / 4-1 \mathrm{~b} . \\ \$ .05 & \$ .25 & \$ .75 \\ .05 & .20 & .60\end{array}$

\section{Hallawell's Quality Pansies}

Pansies thrive best in a partially shaded location, and in a loose soil, well enriched with decayed manure, which should be well dug into the soil. Sow the seed in the fall for early spring blooming. The seed should be sown in boxes, covering them not more than four times their diameter and firming the soil well above them. Do not allow the seed to dry out. The plants must be transplanted twice in order to get the largest flowers; once from the seed box to a sheltered bed and again to the open ground. For best results you must start a good strain. The finest Pansies are, as a rule, shy seeders, which accounts for the difference in price of the various mixtures offered.

Hallawell's Prize Strain: This is a mixture of all the giantflowered varieties, all the plain colors, faced sorts, ruffled edged, and rare sorts; also the varieties exquisitely marbled, striped and blotched. Pkt. of 500 seeds, 50c.

Bugnot Mixed: a ruffled and five-petaled type, with soft, blended colors and tints, veined on the margins and with a dark blotch at the base of each petal. Pkt., 25c.

Cassier's Giant, Mixed : a splendid mixture of various shades and markings: The blossoms are round and are blotched at the base of the petals. Pkt., 25c.

Imperial German Strains Mixed: a fine mixture of choice varieties. $25 \mathrm{c}$.

Giant Masterpiece: these pansies have a combination of rich velvety colors and attractive ruffled petals. $25 \mathrm{c}$.

Giant Trimardeau Mixed: the largest type of pansies; the top petals are larger than the 3 lower ones and are beautifully marked; very sweet scented. $\mathbf{1 5 c}$

Large Flowering Mixed: a mixture of various colors. $10 \mathrm{c}$.

\section{BEST SEPARATE COLORS}

Azure Blue ................... $\mathbf{. 1 0}$

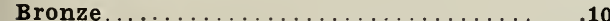

Emperor William: ultramarine blue...... $\quad, 10$

Golden Gem : pure yellow ............... $\mathbf{1 0}$

Golden Yellow : yellow dark eye......... $\quad .10$

Fire King: crimson yellow edge..........

King of the Blacks: velvety black........ $\quad .10$

Lord Beaconsfield: lavender, heliotrope and

purple..................... $\quad .10$

Snow Queen: pure white............. $\quad .10$

Silver Edged : fine.................

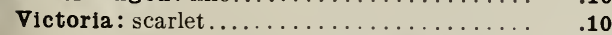

Collection of the above 12 varieties, $\$ 1.00 ;$ or 6 varieties,

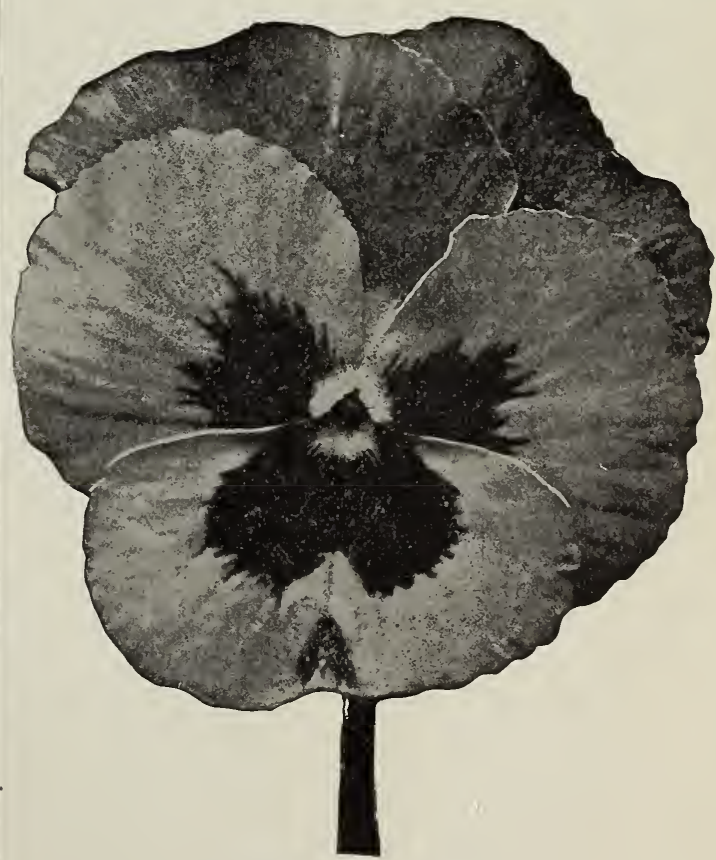

Prize Strain Pansy 


\section{Flower Seeds for Fall Planting}

Pkt

Carnation: Margaret mixed

Centaurea : improved Sweet Sultan mixed.......

Columbine: single or double mixed............. 05

Calendula: Cape Marigold mixed.

Chrysanthemum: annual single mixed

Chrysanthemum: annual double mixed

Canterbury Bells: Cup and Saucer mixed.

Canterbury Bells: single mixed.

Cineraria: Grandiflora mixed

Coreopsis: Grandiflora

Daisy: Snowball or Longfellow

Forget-me-not: blue.

Foxglove: fine mixed.

Galllardia: Grandiflora mixt

Mignonette: sweet or mixed . . . . . . . . . . . .

Pentstemon: fine $\operatorname{mixed} \ldots \ldots \ldots \ldots \ldots \ldots \ldots \ldots \ldots \ldots \ldots . .10$

Poppies: Shirley mixed ........................ 10

Poppies: Oriental scarlet ...................

Snapdragon: Giant mixed.................. 10

Sweet William: single or double mixed .......... 05

Scabiosa: Mam. double mixed ................. .05

Stocks: Emperor or Perpetual mixed............. 15

Stocks : Brompton or Winter mixed ............. .10

Verbenas: Mammoth mixed................ 10

Viola (Tufted Pansies)......................... 10

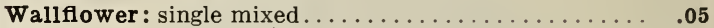

Wallflower: double mixed ................ 10

\section{Select List of Vegetable Seeds FOR FALL AND WINTER PLANTING}

Price per packet 5c except noted otherwise. Prices are postpaid except on peas and onion sets.

If ordered by mail, add 10 cents per pound for postage on Peas and Onion Sets

BEETS-Table Sorts

Improved Blood Turnip . . . ..... \$ $\mathbf{. 2 5}$

Early Eclipse.

Crosby's Egyntian .................

Long Blood Red............. $\quad .15$

Detroit Dark Red............ . .20

Broccoll: large, white.......... 40

BRUSSELS SPROUTS

Half Dwarf . .............. .20

CABB AGE

Early Jersey Wakefield.........

Early Winnigstadt........... .20

Early Flat Dutch........... $\quad . \mathbf{2 5}$

Hollander or Danish Ballhead ....

Premium Flat Dutch......... $\quad .20$

CARROT

Improved Long Orange........ $\quad .25$

Danver's Half Long............ . .25

Oxheart or Guerande.......... . $\quad .30$

Early Scarlet Horn ............. .25

Earliest French Forcing......... .20

\section{CAULIFL OWER}

California Wonder $\ldots \ldots \ldots \ldots \ldots \ldots \ldots \ldots, \$ .10$

Extra Early Snowball ...............

Early Paris . . . . . . . . . . .

COLLARDS

$\mathrm{Oz}$

True Georgia............... \$ .10

\section{LEEK}

American Flag.............

\section{LETTUCE}

Hanson. .

Passion....

Early Curled Simpson

Big Boston

May King. . .

Iceberg.

Los Angeles. ................ 15

\section{ONION}

Extra Early Red Flat......... .20

Yellow Flat Danvers . ........... $\quad .20$

Prizetaker................
$1 / 4-\mathrm{lb}$.

$\$ .75$

.45

Lb. ONIONS

Australian Brown

Oz. $\quad 1 / 4-1 b$

$1 / 4-1 b$
$\$ 0.45$

White Portugal .................

Yellow Globe Danvers......... $\quad .25$

.60

.80

45

.60

1.25

2.00

ONION SETS

Yellow

.75

White. .

1.50

PARSLEY

Extra Triple or Moss Curled...... $\$ .15 \$ \mathbf{~} \$ .35$

PARSNIP

Hollow Crown............ .15 $\quad .45 \quad 1.50$

PEAS

Pkt. Lb.

American Wonder.................. \$ $.10 \quad \$ .25$

Gradus or Prosperity............... .10 $\quad .25$

Little Gem....................... $\quad .10 \quad .25$

Stratagem ........................

Yorkshire Hero.................. $\quad .10 \quad .20$

Champion of England . . . . . . . . . . . .

Telephone......................10

RADISH

Oz. 1/4-lb. Lb.

Scarlet Turnip white tipped ...... $\$ .10 \quad \$ .25$

Early Scarlet Globe ............ $\quad .10 \quad .25$

French Breakfast .............. $\quad .10 \quad .25$

Improved Chartier............ $\quad .10 \quad .25$

Long Scarlet ............... $\quad .10 \quad .20$

Long White Vienna ............ $\quad .10 \quad .25$

Chinese White Winter......... $\quad .10 \quad .25$

SALSIFY

Mammoth Sandwich Island ..... $\quad .20 \quad .50$

$\$ .90$

.75

.75

.75

.60

.75

.90

1.75

SPINACH

Long Standing.............. $\quad .10 \quad .20$

Savoy Leaved .............. $\quad .10 \quad .20$

Prickly .................... . $10 \quad .20$

.50

.50

.50

\section{TURNIP}

Early Snowball............. $\quad .10 \quad .25$

Golden Ball ............... $\quad .10 \quad .20$

Purple Top Strap Leaf......... . $\quad .10 \quad .20$

White Flat Dutch...........

Purple Top White Globe,........ 10

.20

Rutabaga or Swedes, American

.10

.20
.75

.65

.60

.60

.60

.60 


\section{Lawn Grasses}

All our lawn grass seeds are recleaned and of the very best grade. They can be sown in California any time of the year providing there is plenty of water available. Prepare the ground by digging and fertilizing thoroughly with well decayed manure and then rake the surface smoothly. Scatter the seed evenly and rake it in so that it will be covered lightly. After sowing, the ground should be rolled in order to press the seed firmly into the soil. Water daily until well started. One pound of seed is required for 250 square feet of lawn.

Kentucky Blue Grass: Fancy. Extra clean. The most popular grass for lawns. It is dark green and of dense growing habit, making a beautiful turf in a heavy or black soil. Per lb., 25c; per 100 lbs., $\$ 20.00$. postpaid, $35 \mathrm{c}$ per $\mathrm{lb}$.

Shady Nook Mixture: This mixture contains grasses for making good lawns in shady places and under trees. Per lb., 50c; postpaid, 60c per lb.

Hallawell's Special Lawn Mixture: A mixture of several deep green grasses which makes a thick sturdy lawn, remaining green both summer and winter. It is especially adapted for heavy or black soils. Per lb., $35 \mathrm{c}$; postpaid, $45 \mathrm{c}$.
Pacific Rye Grass: This grass is similar to the Australian Rye Grass, but has a finer leaf and is longer lived. Per lb., 25c; per 100 lbs., \$20.00; postpaid, 35c. per lb.

White Clover: Of dwarf habit with creeping stems, rooting at the joints, on which account it makes an excellent turf that stands constant tramping. Planted for a lawn either alone or in mixture with grass seed. Price per lb., 60c; per lb. postpaid, 70c.

Australian Rye Grass: A very vigorous, quick-growing lawn grass, but a little coarse. Very satisfactory for lawns in San Francisco. Per lb., 15c; 100 lbs., $\$ 10.00$; postpaid, 25c per lb.

\section{High Grade Fertilizers}

The Pacific Guano \& Fertilizer Co.'s Lawn DressingFor lawns use 2 to 3 pounds to 100 square feet. Sprinkle the lawn lightly after applying fertilizer. Potted plants should be given not more than one to three teaspoonfuls per cubic foot of soil; shrubs from $\frac{1}{2}$ to $1 \mathrm{lb}$. according to size of shrub. $10 \mathrm{lb}$. bag, 60c; $25 \mathrm{lb}$. bag, $\$ 1.25 ; 50 \mathrm{lb}$. bag, $\$ 2.00 ; 100 \mathrm{lb}$. bag, $\$ 3.50$.
Pure Ground Blood and Bone Meal: Finely pulverized; excellent for rose-culture. It decomposes very rapidly, and is more quickly effective than the coarser grades. It is excellent for mixing with the soil for potting. $\quad 5$ lbs., $25 \mathrm{c} ; 50 \mathrm{lbs}$, $\$ 1.50 ; 100 \mathrm{lbs}$, $\$ 2.50$.

\section{Hallawell's Annual Catalogue for 1913}

Our catalogue of Roses, Dahlias, Gladioli, Fruit Trees, Flower and Vegetable Seeds, etc., will be ready for distribution some time in December. WE WOULD BE PLEASED TO RECEIVE IT. 


\section{Collection of Spencer Sweet Peas}

Asta Ohn-Lavender.

Apple Blossom Spencer-Crimson with white wings tinted pink.

Aurora Spencer-Striped orange pink.

Captain of the Blues Spencer-Purple.

Countess Spencer-Bright pink.

Florence Morse Spencer - White and blush pink with deeper pink margin.

Geo. Herbert-Rose Carmine.
Helen Lewis-Orange pink.

King Edward Spencer-Best pure red. Mrs. Routzahn-Soft chamois pink. Othello Spencer-Very dark maroon. Primrose Spencer-Pale yellow.

Prince of Wales Spencer-Bright rosy red. Queen Alezandra Spencer-New bright scarlet.

White Spencer-Pure white.

One packet each of the above 15 varieties for $\$ 1.00$.

\section{5 \\ Hallawell's \\ Prize Strain Pansies}

Packet of 500 seeds for 50 cents.

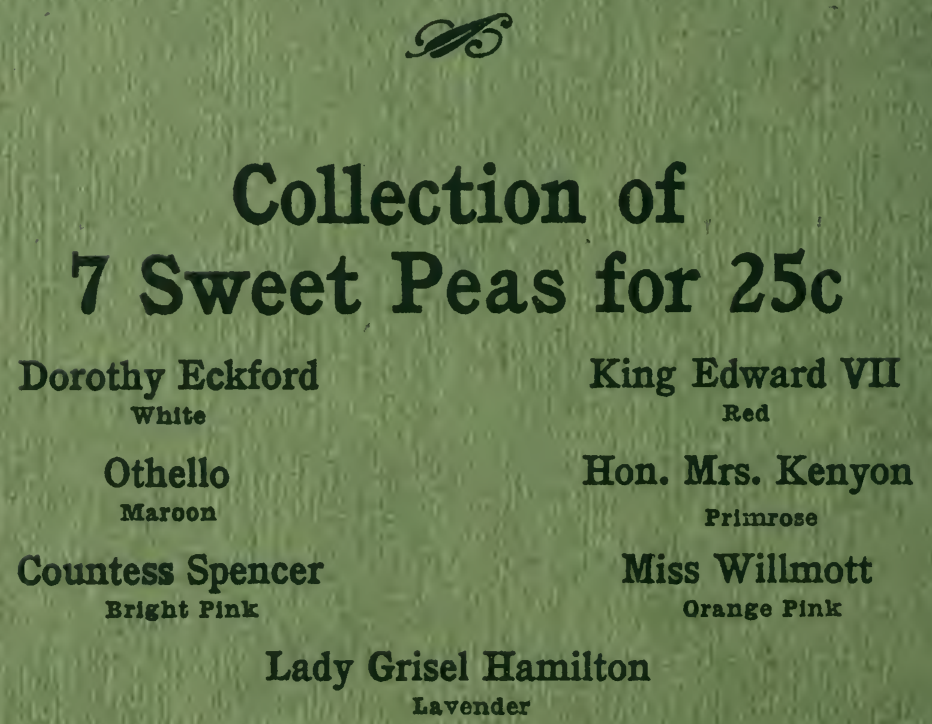

Iavender 